\title{
Morphological Characteristics of Thymus in the Newborns in Different Climatic and Geographical Conditions of Kyrgyzstan
}

\author{
Tamara Abaeva1, Zhanibek Muratov², Rustam Tukhvatshin ${ }^{3}$, Zhypargul Abdullaeva ${ }^{4,5^{*}}{ }^{\circledR}$, \\ Aziza Seitova' ${ }^{2}$, Veronika Tursunova6, Mira Zhanganaeva1, Masalbek Satybaldiev', \\ Lazokatkhan Dzhumaeva", Meerim Abdyraimova ${ }^{4}$, Feruza Mamasadykova ${ }^{6}$, Aiperi Alimbekova ${ }^{4}$ \\ ${ }^{1}$ Department of Normal and Topographic Anatomy of I.K. Akhunbaev, Kyrgyz State Medical Academy, Bishkek, Kyrgyzstan \\ ${ }^{2}$ Department of Pathology, Basic and Clinical Pharmacology, International Medical Faculty, Osh State University, Osh, Kyrgyzstan \\ ${ }^{3}$ Department of Pathological Physiology, I.K. Akhunbaev Kyrgyz State Medical Academy, Bishkek, Kyrgyzstan \\ ${ }^{4}$ Department of Anatomy, Histology and Normal Physiology, International Medical Faculty, Osh State University, Osh, Kyrgyzstan \\ ${ }^{5}$ Science and Research Department, Osh State University, Osh, Kyrgyzstan \\ ${ }^{6}$ Department of Clinical Disciplines 2, International Medical Faculty, Osh State University, Osh, Kyrgyzstan \\ Email: *jypar.science@oshsu.kg
}

How to cite this paper: Abaeva, T., Muratov, Z., Tukhvatshin, R., Abdullaeva, Z., Seitova, A., Tursunova, V., Zhanganaeva, M., Satybaldiev, M., Dzhumaeva, L., Abdyraimova, M., Mamasadykova, F. and Alimbekova, A. (2020) Morphological Characteristics of Thymus in the Newborns in Different Climatic and Geographical Conditions of Kyrgyzstan. International Journal of Medical Physics, Clinical Engineering and Radiation Oncology, 9, 178-185.

https://doi.org/10.4236/ijmpcero.2020.94016

Received: September 4, 2020

Accepted: October 9, 2020

Published: October 12, 2020

Copyright $\odot 2020$ by author(s) and Scientific Research Publishing Inc. This work is licensed under the Creative Commons Attribution International License (CC BY 4.0).

http://creativecommons.org/licenses/by/4.0/

\begin{abstract}
This paper is describing a detailed study of morphological structures and characteristics newborns thymus in different climatic and geographical conditions of Kara-Balta, Cholpon-Ata, and Bishkek in Kyrgyzstan. Anatomical structure research done on 26 thymuses of newborn corpses. Research results showed that a significant amount of thymuses consisted of lobes with very thin connective tissues between them. It is observed that the Hassall cells were usually located in the medulla part of the thymus after using the coloring by Van-Gieson's stain visible clear elastic and collagen fibers. In addition, cell population dynamics in a unit of conditional area of cortical substance thymus lobes in newborns determined.
\end{abstract}

\section{Keywords}

Thymus, Newborns, Hassall Cells, Climatic Conditions, Histological Methods

\section{Introduction}

The thymus gland [1] [2] [3] belongs to the central organs of the immune system responsible for the formation and maintenance of the body's biological defenses. The thymus is an important organ regulating the immune system with immunologic function closely dependent on the presence of normal thymic structures 
[4]. Histologically, the thymus can be divided into two subcompartments such as the: cortex and the medulla each of which contains distinct populations of thymic epithelial cells (TECs), as well as mesenchymal cells, endothelial cells, and dendritic cells [5]. The thymus reaches its maximum weight during the puberty period and subsequently undergoes involution [6]. Thymus functions are important in providing a suitable microenvironment for the proliferation, differentiation, TCR gene rearrangement, and selection of T cells as shown in the Figure 1 [7] [8] [9] [10] [11].

Experts in the field of immunomorphology [12] define the immune system as a set of organs, tissues, and cells, whose work aimed directly at protecting the body from various diseases and at destroying foreign substances that have already entered the body. The immune system is an obstacle to infections (bacterial, viral, fungal). When the immune system malfunctions, the likelihood of infection increases, it also leads to the development of autoimmune diseases by activation of autoimmunity [13] as represented in the Figure 2, knowledge of the age characteristics of structure and functions of the immune system organs, in particular, the thymus gland is relevant for determining periods of immunogenesis at critical moments during the postnatal period. The neonatal period characterized by the impairment of the major components of both innate and adaptive immunity; however, there is a lack of information about the neonatal condition of the thymus gland, a key organ for efficient immune system maturation [14]. These data are in demand in clinical medicine for the proper organizlation of

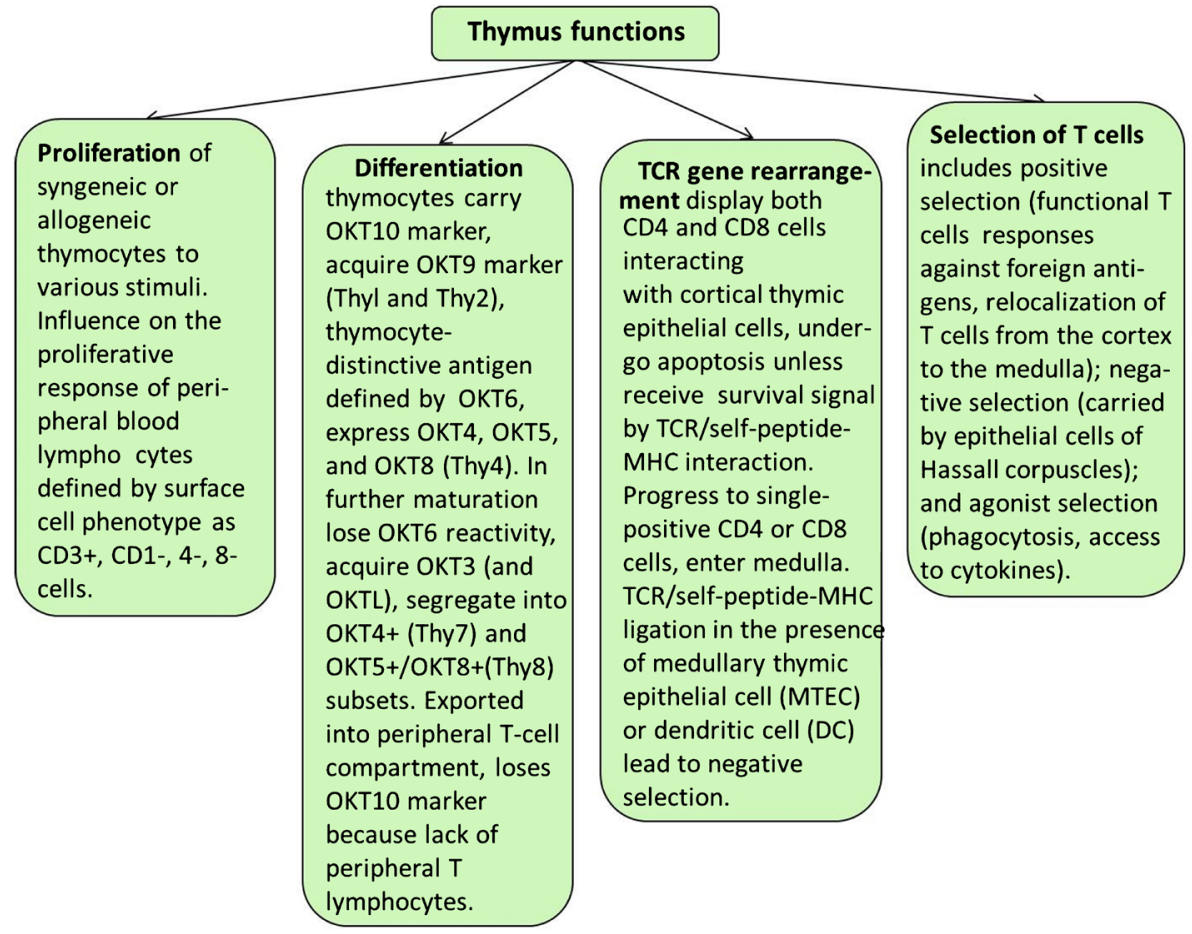

Figure 1. Example of the thymus and its functions as an important organ providing microenvironment for thymocytes proliferation, differentiation, TCR gene rearrangement, and various selections (adapted from ref. [7] [8] [9] [10] [11]). 


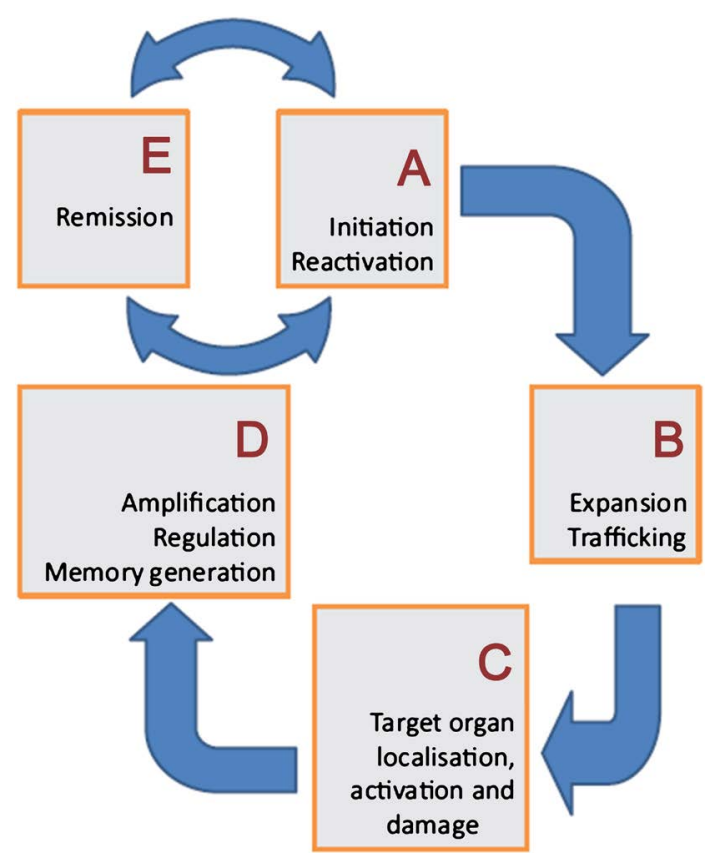

Figure 2. Overview of autoimmunity. An autoimmune episode starts (A) with the initiation or reactivation of an immune attack directed against self. The T-cells expand and traffic (B) to the site where the antigen is found, are activated and damage the tissue (C). With time, the response is regulated and subsides, although the immune memory remains (D). Future infection may then trigger a relapse of the remission (E) (reproduced from [13]).

preventive and therapeutic measures [15]. It was reported that the number and size of Hassall's corpuscles of different maturity invertebrate animals and humans depend on age and the environmental conditions [16].

The Hassall's corpuscles (HC) usually have dimensions ranging from 20 to 150 microns in bovines, from 10 to 1000 microns in other species, and located in the medulla of the mammalian thymus [17]. Small Hassall's corpuscles consisted of type- 6 epithelial cells, while in larger corpuscles many nuclei of type- 6 cells ("large-medullary" cells) [18].

\section{Research Methods}

The following research methods used in the course of this study: 1) Anatomical methods used including preparation on cadaver, sample isolation, mass weighing and size measurement; 2) Histological methods applied such as cleaning in the ethanol and xylol coloring by hemotoxylin-eosin, according to Van-Gieson's stain, and observations under microscope. Materials and objects: The anatomy of the thymus gland was studied on 26 corpses of newborns who were died in the neonatal period from causes not associated with immune-deficient conditions. Microscope (MBS), camera (Canon), and computer software program. Methods: Student's t-test used based on the mean of the comparison values. Peculiarities of using the Student's t-test include multiple comparisons such as: pairwise differences of more than two samples, multiple pairwise comparisons, the probability of error 
differences [19].

\section{Results and Discussions}

The thymus gland is a small organ of pinkish-gray color and with a soft consistency. The thymus develops from a paired epithelial anlage in the neck [20]. Although the thymus has enormous regenerative capacity during fetal development, the regenerative capacity of the human postnatal thymus decreases over time [21]. Morphometric proportions of the thymus individual lobes analyzed as represented in Table 1, where the left thymus lobe is longer and thicker compared to the right lobe [22].

Thymus index as represented in Figure 3 obtained by measuring the width of the thymus in a transverse image while the area of the largest lobe assessed in a longitudinal image [23]. In newborns we have observed, the longitudinal dimensions of the thymus were ranged from 4.7 to $7.6 \mathrm{~cm}$ (average is $6 \mathrm{~cm}$ ), the left lobe, from 5 to $5.7 \mathrm{~cm}$ (average is $5 \mathrm{~cm}$ ). The transverse dimensions of the right lobe vary from 1.8 to $2.4 \mathrm{~cm}$ (average is $2 \mathrm{~cm}$ ), the left one from 1.5 to $3.3 \mathrm{~cm}$ (average is $2 \mathrm{~cm}$ ). The thickness of the right lobe varies from 0.7 to $1.3 \mathrm{~cm}$ (average is $1 \mathrm{~cm}$ ). The upper border of the thymus gland is located on the cuttings of

Table 1. Morphometry of thymus in a group of 212 full-term newborns [22].

\begin{tabular}{|c|c|c|c|}
\hline $\mathrm{n}=212$ & & Right lobe of thymus & Left lobe of thymus \\
\hline Length of the lobe (mm) & Mean & 34.64 & 36.19 \\
\hline $\mathrm{P}=0.117$ & SD & 4.51 & 4.20 \\
\hline Width of the lobe (mm) & Mean & 13.79 & 12.76 \\
\hline $\mathrm{P}=0.035$ & $\mathrm{SD}$ & 2.68 & 2.53 \\
\hline The thickness of lobe (mm) & Mean & 13.57 & 14.01 \\
\hline $\mathrm{P}=0.004$ & $\mathrm{SD}$ & 1.78 & 1.77 \\
\hline The volume of the lobe $\left(\mathrm{cm}^{3}\right)$ & Mean & 6.66 & 6.65 \\
\hline $\mathrm{P}=0.194$ & $\mathrm{SD}$ & 2.34 & 2.20 \\
\hline The volume of two lobes together $\left(\mathrm{cm}^{3}\right)$ & Mean & 13.22 & - \\
\hline
\end{tabular}

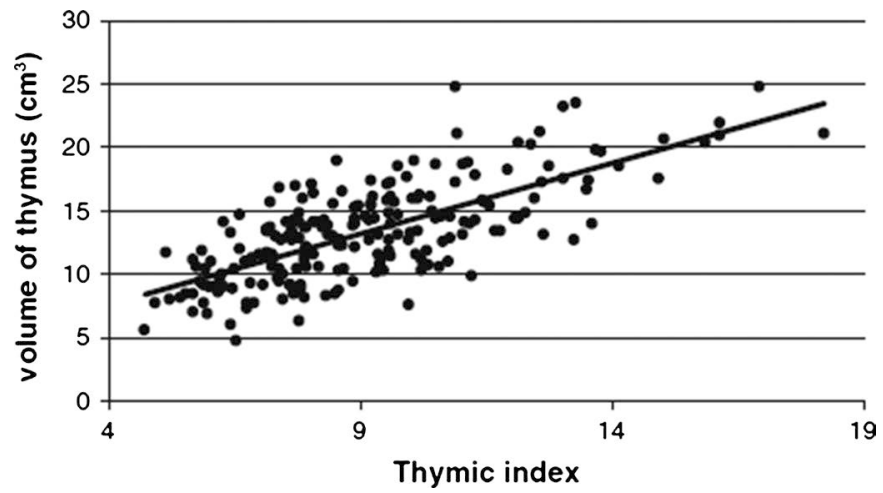

Figure 3. Example ofScatter plot of the volume of thymus against the value of Thymus index (Spearmans' $\mathrm{r}=0.675 ; \mathrm{P} / 0.001)[23]$. 
the sternum handle or 1.5 to $2.5 \mathrm{~cm}$ above it. The border of the right lobe is usually somewhat higher than the left.

The lower border of the gland extends beyond the body and the handle of the sternum to the right from 0.6 to $2.0 \mathrm{~cm}$ (average is $1 \mathrm{~cm}$ ), to the left from 1 to $1.25 \mathrm{~cm}$ (average is $1 \mathrm{~cm}$ ).

The thymus gland has a delicate thin connective tissue capsule, consisting predominantly of elastic fibers, among the fibers, are revealed collagen fibers (when stained according to Van-Gieson's stain) as shown in the Figure 4(A). The cortical layer contains a large number of lymphocytes located compactly. On the periphery of the cortical layer, lymphoblasts are found under the capsule (20\%). Lymphoblasts are also found in the medulla (30\%), but significantly less than in the cortical (50\%). Hassall corpuscles found in the medulla (65\%), Hassall's large corpuscles found in the center of the lobules (10\%) as shown in Figure 4(B). The interlobular interlayers contain the plexus of the lymphatic vessels. The vascular wall in $2 \%$ of cases, was thickened and sclerosed as it can be seen in Figure 4 and Figure 5.

The dynamics of cell populations in the unit of the conditional area of the cortical substance of the thymus lobules in newborns (Table 2) are shown. In Bishkek city, lymphoblasts are $26.6 \pm 3.0$, the city of Cholpon-Ata $24.7 \pm 0.5$, and

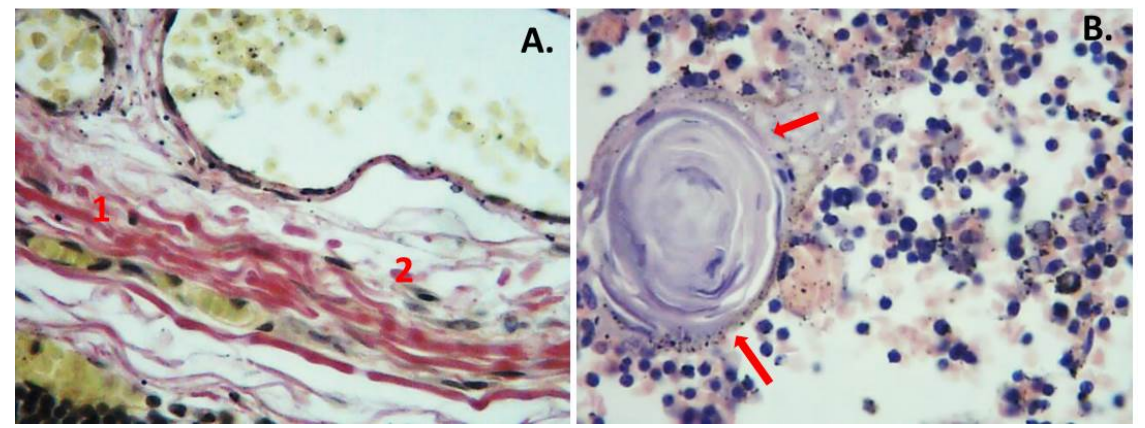

Figure 4. (A) Photomicrograph of collagen (1), and reticular fibers (2) in the cortical layer of the thymus of the 2 days old newborn $(40 \times 20)$. (B) Photomicrograph of the medulla (shown by arrows), surrounded by Hassall's corpuscles keratinized formations with mature epithelial cells (original magnification 40; H-E stain).

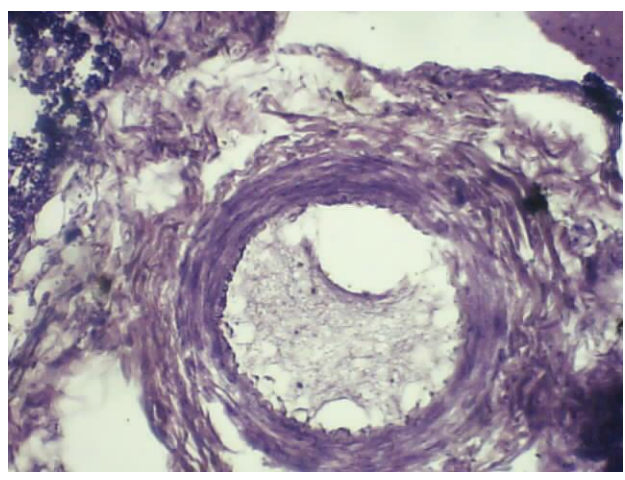

Figure 5. Atrophy, thickened vessel walls, and the collagen fibers around the vessel (objective 40, ocular 20). 
Table 2. Cell population dynamics in a unit of conditional area of cortical substance thymus lobes in newborns.

\begin{tabular}{cccc}
\hline Cell populations & Bishkek & Kara-Balta & Cholpon-Ata \\
\cline { 2 - 4 } & \multicolumn{3}{c}{ M $\pm \mathrm{m}$} \\
\hline Lymphoblasts & $26.4 \pm 0.3$ & $28.9 \pm 0.5^{*}$ & $27.7 \pm 0.7$ \\
Medium lymphocytes & $44.2 \pm 0.4$ & $51.5 \pm 0.6^{*}$ & $63.7 \pm 0.7^{*}$ \\
Small lymphocytes & $285.2 \pm 0.7$ & $297.0 \pm 1.5^{*}$ & $301.7 \pm 2.3^{*}$ \\
Apoptotic body & $63.5 \pm 0.4$ & $69.5 \pm 1.5^{*}$ & $61.1 \pm 0.4^{*}$ \\
Mitosis & $18.1 \pm 0.5$ & $23.9 \pm 0.5^{*}$ & $23.9 \pm 0.5^{*}$ \\
Macrophages & $6.2 \pm 0.3$ & $7.7 \pm 0.3^{*}$ & $6.6 \pm 0.3$ \\
Hassall's bodies & $4.5 \pm 0.3$ & $6.1 \pm 0.3^{*}$ & $6.2 \pm 0.3^{*}$ \\
Total number of cells & 451.52 .6 & $471.8 \pm 1.8^{*}$ & $489.1 \pm 3.3^{*}$ \\
\hline
\end{tabular}

Table 3. The stereometric characteristic of the thymus of the newborn $(\mathrm{M} \pm \mathrm{m})$ in $\%$.

\begin{tabular}{cccc}
\hline Cortical substance & $64.5 \pm 0.4$ & $72.7 \pm 0.5^{\star}$ & $78.6 \pm 0.5^{*}$ \\
Brain substance & $28.0 \pm 0.5$ & $29.5 \pm 0.7$ & $26.6 \pm 0.4^{*}$ \\
VPP & $4.5 \pm 0.4$ & $5.8 \pm 0.3^{*}$ & $3.7 \pm 0.2$ \\
Interlobular septa & - & $2.9 \pm 0.2$ & $2.5 \pm 0.1^{*}$ \\
\hline
\end{tabular}

in the city of Kara-Balta, $28.9 \pm 0.5$. The small lymphocytes of Bishkek city are $285.2 \pm 0.7$, the city of Kara-Balta $297.0 \pm 1$, the city of Cholpon-Ata $301.7 \pm 2.3$.

The stereometric characteristics of the neonatal thymus (Table 3) show a cortical substance in Bishkek $64.5 \pm 0.4$, Kara-Balta $72.7 \pm 0.5$, Cholpon-Ata 78.6 \pm 0.5 . The brain substance in Bishkek was $28.0 \pm 0.5$, in Kara-Balta $29.5 \pm 0.7$, and Cholpon-Ata $26.6 \pm 0.4$.

The thymus body has a lobed structure, with different sizes of the lobules. Between the lobes tender connective tissue, consisting mainly of elastic fibers.

\section{Conclusion}

Stereometric characteristics of neonatal thymus in Bishkek show a cortical substance $64.5 \pm 0.4$, in Karabalta was $72.7 \pm 0.5$, and in Cholponata was $78.6 \pm 0.5$. The brain substance in Bishkek was $28.0 \pm 0.5$, in Karabalta $29.5 \pm 0.7$, and Cholponata $26.6 \pm 0.4$. Hassall's tissue found within normal limits. Lymphoblasts were located in places form significant clusters. The walls of individual vessels were infiltrated with lymphoblasts.

\section{Ethical Statement}

The authors declare that the research conducted in the absence of any commercial or financial relationships that construed as a potential conflict of interest.

\section{Ethical Approval}

All procedures performed in studies involving human participants were follow- 
ing the ethical standards of the institutional and/or national research committee and with the 1964 Helsinki declaration and its later amendments or comparable ethical standards.

\section{Conflicts of Interest}

The authors declare no conflicts of interest regarding the publication of this paper.

\section{References}

[1] Shields, T.W. (1969) The Thymus Gland. Surgical Clinics of North America, 49, 61-70. https://doi.org/10.1016/S0039-6109(16)38736-9

[2] Pearse, G. (2006) Normal Structure, Function and Histology of the Thymus. Toxicologic Pathology, 34, 504-514. https://doi.org/10.1080/01926230600865549

[3] Yekeler, E., Tambag, A., Tunaci, A., Genchellac, H., Dursun, M., Gokcay, G. and Acunas, G. (2004) Analysis of the Thymus in 151 Healthy Infants from 0 to 2 Years of Age. Journal of Ultrasound in Medicine, 23, 1321-1326. https://doi.org/10.7863/jum.2004.23.10.1321

[4] Hofmann, W.J. and Otto, H.F. (1992) Anatomy and Embryology of the Thymus. In: Walter, E., Willich, E. and Webb, W.R., Eds., The Thymus, Springer, Berlin, 5-13.

[5] Gordon, J. and Manley, N.R. (2011) Mechanisms of Thymus Organogenesis and Morphogenesis. Development, 138, 3865-3878. https://doi.org/10.1242/dev.059998

[6] Nishino, M., Ashiku, S.K., Kocher, O.N., Thurer, R.L., Boiselle, P.M. and Hatabu, H. (2006) The Thymus: A Comprehensive Review. Radiographics, 26, 335-348. https://doi.org/10.1148/rg.262045213

[7] Jablonska-Mestanova, V., Sisovsky, V., Danisovic, L., Polak, S. and Varga, I. (2013) The Normal Human Newborns Thymus. Bratislavske Lekarske Listy, 114, 402-408. https://doi.org/10.4149/BLL 2013086

[8] Gelin, C., Boumsell, L. and Bernard, A. (1986) Control of Cell Proliferation within the Human Thymus. A Very Limited Thymocyte Subpopulation Generates a Suppressive Activity. European Journal of Immunology, 16, 1209-1216. https://doi.org/10.1002/eji.1830161005

[9] Reinherz, E.L., Kung, P.C., Goldstein, G., Levey, R.H. and Schlossman, S.F. (1980) Discrete Stages of Human Intrathymic Differentiation: Analysis of Normal Thymocytes and Leukemic Lymphoblasts of T-Cell Lineage. Proceedings of the National Academy of Sciences of the United States of America, 77, 1588-1592. https://doi.org/10.1073/pnas.77.3.1588

[10] Griesemer, A.D., Sorenson, E.C. and Hardy, M.A. (2010) The Role of the Thymus in Tolerance. Transplantation, 90, 465-474. https://doi.org/10.1097/TP.0b013e3181e7e54f

[11] Raica, M., Encică, S., Motoc, A., Cîmpean, A.M., Scridon, T. and Bârsan, M. (2006) Structural Heterogeneity and Immunohistochemical Profile of Hassall Corpuscles in Normal Human Thymus. Annals of Anatomy-Anatomischer Anzeiger, 188, 345-352. https://doi.org/10.1016/j.aanat.2006.01.012

[12] Khlystova, Z.S., Shmeleva, S.P., Ryabchikov, O.P., Tokareva, O.I. and Grigor'eva, I.I. (1979) Structural and Immunomorphological Characteristics of the Human Thymus during Embryonic Development. Bulletin of Experimental Biology and Medicine, 88, 793-797. https://doi.org/10.1007/BF00804797 
[13] Nicholson, L.B. (2016) The Immune System. Essays in Biochemistry, 60, 275-301. https://doi.org/10.1042/EBC20160017

[14] Varas, A., Jiménez, E., Sacedón, R., Rodríguez-Mahou, M., Maroto, E., Zapata, A.G. and Vicente, A. (2000) Analysis of the Human Neonatal Thymus: Evidence for a Transient Thymic Involution. The Journal of Immunology, 164, 6260-6267. https://doi.org/10.4049/jimmunol.164.12.6260

[15] Tajima, A., Pradhan, I., Trucco, M. and Fan, Y. (2016) Restoration of Thymus Function with Bioengineered Thymus Organoids. Current Stem Cell Reports, 2, 128-139. https://doi.org/10.1007/s40778-016-0040-x

[16] Yurchinskij, V.J. (2016) Age-Related Morphological Changes in Hassall's Corpuscles of Different Maturity in Vertebrate Animals and Humans. Advances in Gerontology, 6, 117-122. https://doi.org/10.1134/S2079057016020156

[17] Asghar, A., Syed, Y.M. and Nafis, F.A. (2012) Polymorphism of Hassall's Corpuscles in Thymus of Human Fetuses. International Journal of Applied \& Basic Medical Research, 2, 7-10. https://doi.org/10.4103/2229-516X.96791

[18] Van de Wijngaert, F.P., Kendall, M.D., Schuurman, H.J., Rademakers, L.H.P.M. and Kater, L. (1984) Heterogeneity of Epithelial Cells in the Human Thymus. Cell and Tissue Research, 237, 227-237. http://dx.doi.org/10.1007/BF00217140

[19] Ilyin, V.P. (2011) Methodological Features of the Student's t-test in Biomedical Research. Acta Biomedica Scientifica, 5, 160-161.

[20] Von Gaudecker, B. (1991) Functional Histology of the Human Thymus. Anatomy and Embryology, 183, 1-15. https://doi.org/10.1007/BF00185830

[21] Haynes, B.F. and Hale, L.P. (1998) The Human Thymus. Immunologic Research, 18, 61-78. https://doi.org/10.1007/BF02788750

[22] Varga, I., Uhrinova, A., Toth, F. and Mistinova, J. (2011) Assessment of the Thymic Morphometry Using Ultrasound in Full-Term Newborns. Surgical and Radiologic Anatomy volume, 33, 689-695. https://doi.org/10.1007/s00276-011-0806-X

[23] Moore, S., Prentice, A., Wagatsuma, Y., Fulford, A., Collinson, A., Raqib, R., Vahter, M., Persson, L. and Arifeen, S. (2009) Early-Life Nutritional and Environmental Determinants of Thymic Size in Infants Born in Rural Bangladesh. Acta Pædiatrica, 98, 1168-1175. https://doi.org/10.1111/j.1651-2227.2009.01292.x 